IZA DP No. 8616

Estimating the Returns to Schooling Using Cohort-Level Maternal Education as an Instrument

John V. Winters

November 2014 


\title{
Estimating the Returns to Schooling Using Cohort-Level Maternal Education as an Instrument
}

\author{
John V. Winters \\ Oklahoma State University \\ and IZA
}

\section{Discussion Paper No. 8616 \\ November 2014}

\author{
IZA \\ P.O. Box 7240 \\ 53072 Bonn \\ Germany \\ Phone: +49-228-3894-0 \\ Fax: +49-228-3894-180 \\ E-mail: iza@iza.org
}

Any opinions expressed here are those of the author(s) and not those of IZA. Research published in this series may include views on policy, but the institute itself takes no institutional policy positions. The IZA research network is committed to the IZA Guiding Principles of Research Integrity.

The Institute for the Study of Labor (IZA) in Bonn is a local and virtual international research center and a place of communication between science, politics and business. IZA is an independent nonprofit organization supported by Deutsche Post Foundation. The center is associated with the University of Bonn and offers a stimulating research environment through its international network, workshops and conferences, data service, project support, research visits and doctoral program. IZA engages in (i) original and internationally competitive research in all fields of labor economics, (ii) development of policy concepts, and (iii) dissemination of research results and concepts to the interested public.

IZA Discussion Papers often represent preliminary work and are circulated to encourage discussion. Citation of such a paper should account for its provisional character. A revised version may be available directly from the author. 
IZA Discussion Paper No. 8616

November 2014

\section{ABSTRACT}

\section{Estimating the Returns to Schooling Using Cohort-Level Maternal Education as an Instrument}

Formal education is widely thought to be a major determinant of individual earnings. This paper uses the American Community Survey to examine the effect of formal schooling on worker wages. Given the potential endogeneity of education decisions, I instrument for individual schooling using cohort-level mean maternal years of schooling from previous decennial censuses. The instrumental variables results suggest that schooling has a significant positive effect on worker wages. Specifically, an additional year or schooling is estimated to increase hourly wages by 10 percent for men and 12.6 percent for women.

JEL Classification: J24, J31

Keywords: returns to schooling, education, human capital, wages, maternal education

Corresponding author:

John V. Winters

Oklahoma State University

331 Business Building

Stillwater, OK 74078-4011

USA

E-mail: jvwinte@okstate.edu 


\section{Introduction}

Numerous studies show that persons with higher schooling earn higher wages; see reviews by Card (1999) and Psacharopoulos and Patrinos (2004). The returns to education (RTE) literature largely focuses on causal effects of education on earnings. Estimating causal effects of education on earnings is complicated by the likelihood that persons with greater ability complete more education. Many studies try to directly control for ability and find that doing so reduces ordinary least squares (OLS) RTE estimates by roughly 10 percent (Card 1999). Researchers also attempt to estimate causal effects using instrumental variables (IV) and frequently find that IV estimates exceed OLS estimates (Card 1999).

This paper contributes to the literature estimating causal effects of education on earnings. I first use the 2006-2012 American Community Survey (ACS) to obtain OLS RTE estimates for non-Hispanic whites. I then estimate causal effects of education on wages utilizing a novel instrument based on cohort-level average maternal education from past censuses. I include birth state fixed effects, so identification comes from variation across cohorts within states.

Researchers have used parental education as instruments for individual schooling (Hoogerheide et al. 2012), but to my knowledge other researchers have not used cohort-level variation in maternal education within states. ${ }^{1}$ According to IV results, an additional year of schooling increases hourly wages by 10 percent for men and 12.6 percent for women. These estimates are similar to OLS estimates and well within the range of IV estimates from recent studies.

\footnotetext{
${ }^{1}$ Winters (2014) uses a similar IV strategy to estimate the relationship between the production and stock of college graduates for US states.
} 


\section{Data and Empirical Approach}

I regress log wages on schooling and other variables:

$\log W_{i s c t a}=\alpha+\beta$ Schooling $_{i s c t a}+\delta_{s}+\varphi_{c}+\theta_{t}+\pi_{a}+\varepsilon_{\text {iscta }}$

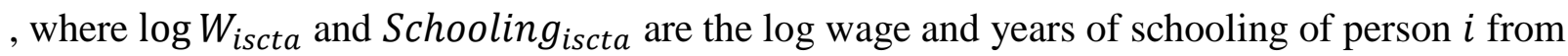
birth state $s$ and year-of-birth cohort $c$ observed in survey year $t$ at age $a$. State fixed effects $\left(\delta_{s}\right)$ control for persistent differences across birth states; identification comes from differences across cohorts within states. I include dummy variables for survey year $\left(\theta_{t}\right)$, age $\left(\pi_{a}\right)$, and year of birth $\left(\varphi_{c}\right)$. I cluster standard errors by birth state.

Data for individual wages and education come from the 2006-2012 ACS accessed from IPUMS (Ruggles et al. 2010). Respondents report annual wage and salary income over the past 12 months and I examine log annual wages as one dependent variable. Many studies are primarily interested in log hourly wages and I consider this as another dependent variable. I also examine log annual hours worked.

I compute hourly wages as annual wages divided by estimated annual hours. The ACS reports usual hours worked per week and provides information on weeks worked the previous year. For 2006-2007, the ACS reports the actual number of weeks worked, but in 2008 the ACS began reporting weeks worked only in intervals. I computed mean weeks worked by sex for each interval in 2006-2007 and assign those interval means to all persons within the interval for the entire sample period. ${ }^{2}$ I then multiply usual hours per week by the estimated number of weeks worked to compute annual hours worked. I divide annual wages by annual hours to get hourly wages.

\footnotetext{
${ }^{2}$ Interval means are used for 2006-2007 to preserve comparability with other years.
} 
The ACS reports the highest level of education for each individual. I convert this to years of schooling based on the normal time required. The ACS also reports individual age and state of birth. I compute each individual's year of birth as the difference between the survey year and age at the time of the survey.

The sample is restricted to non-Hispanic whites born in the 50 U.S. states with hourly wages between $\$ 5$ and $\$ 500$ and excludes self-employers. The minimum wage exceeded $\$ 5$ per hour throughout this period, so wages below \$5 likely result from measurement error. Similarly, some workers have very high wages and are excluded to prevent them from disproportionately affecting the results. I also restrict the sample to persons at least age 25, and the instrument used restricts the sample to persons born since 1963; I restrict the OLS sample to these same birth cohorts to facilitate comparability. The oldest cohorts reach age 49 by 2012.

I first estimate equation (1) using OLS, but the main contribution comes from 2SLS. Individual education is likely correlated with unobserved ability, which would upwardly bias OLS estimates. The 2SLS estimates instrument for individual schooling using mean maternal schooling by birth state and cohort computed from the 1980 and 1990 decennial census 5\% PUMS. ${ }^{3}$ I merge cohort-level maternal education to relevant cohorts in the 2006-2012 ACS by birth state and year of birth. A large literature finds strong positive effects of maternal education on child education (Behrman and Rosenzweig 2002; Björklund and Salvanes 2011).

Maternal education is only measurable for persons living in the same household as their mother. Since individuals often move out of their parents' houses starting at age 18, maternal

\footnotetext{
${ }^{3}$ I could use paternal education as an instrument, but many children live apart from their father, so cohort-level paternal education is likely a less reliable instrument.
} 
education is measured only for children age 17 or younger in the 1980 or 1990 census surveys. This restricts the instrument to persons born in 1963 or later. ${ }^{4,5}$

Some children do not live in the same household as their mother, and some live with a stepmother or adoptive mother. I treat all "mothers" in the same household as their children equivalently. Children who live with no mother are excluded. Fortunately, 93 percent of children ages 0-17 have a "mother" in the household so cohort-level maternal education is reasonably accurately estimated. To match the ACS analysis sample, I restrict the maternal education sample to non-Hispanic white children. For children with maternal education available, I compute mean years of schooling of their mother by state-of-birth and year-of-birth cohort.

A valid instrument is both relevant and exogenous. Relevant means that the instrument is strongly correlated with the potentially endogenous explanatory variable, i.e., the maternal education instrument should have a strong statistically significant effect on schooling in the first stage of the 2SLS regression. I test this assumption below. Exogeneity means the instrument is uncorrelated with the error term in the log wage equation. With only one instrument, I cannot test the exogeneity condition, but one can intuitively argue that the cohort level maternal education instrument is likely exogenous. First, the instrument is measured using 1980 and 1990 data and the dependent variable is first observed in 2006, so the instrument is not affected by contemporaneous labor market conditions that jointly affect recent employment and education outcomes. More importantly, the instrument is measured as a cohort-level mean using a five

\footnotetext{
${ }^{4}$ One could use the 1970 Census for older cohorts, but I decided against doing so because the 1970 sample is smaller and would produce noisier measures. Older cohorts are also closer to retirement and create additional complications.

${ }^{5}$ Cohorts born 1973-1980 were under age 18 in both 1980 and 1990 . I measure maternal education levels for these cohorts using the 1990 census, but using the 1980 census for these produces similar results.
} 
percent sample of the population. Thus, it is not directly based on the actual mothers of ACS respondents. ${ }^{6}$ Using actual mothers' education could be problematic if unobserved maternal ability is correlated with both maternal education and unobserved child ability. But because the instrument uses cohort-level means of maternal schooling levels, it is based on average maternal education among one's peers. Furthermore, regressions include state-of-birth and year-of-birth fixed effects, which account for unobserved differences across birth states and years.

Identification comes from cohort-level variation in maternal education within birth states. This variation is likely due to largely random factors such as state and local education policies and changing expectations about female education, labor force participation, and fertility that affected states differently at different times.

\section{Empirical Results}

Panel A of Table 1 presents OLS estimates. ${ }^{7}$ Schooling has a statistically significant positive effect on annual wages, annual hours worked and hourly wages of both men and women. For men an additional year of schooling increases annual wages by 12.4 percent, annual hours by 2.8 percent and hourly wages by 9.7 percent. $^{8}$ For women schooling increases annual wages by 13.4 percent, annual hours by 2.7 percent, and hourly wages by 10.7 percent.

Panel B presents 2SLS results. The first stage is estimated separately for men and women but does not differ between the three second-stage outcomes. The instrument significantly increases schooling; first-stage instrument F-statistics exceed 10, minimizing weak instrument concerns (Angrist and Pischke 2009).

\footnotetext{
${ }^{6}$ Five percent of the ACS sample is included in the census data, but we cannot link persons across surveys.

${ }^{7}$ Analysis was conducted using Stata MP 13.0.

${ }^{8}$ Because of properties of logs, these two coefficients sum to equal the effect on annual wages with slight rounding error.
} 
Male 2SLS coefficients are similar to OLS. Annual wages and hourly wages coefficients are statistically significant at the five percent level. The coefficient for annual hours is statistically insignificant. An additional year of schooling increases male annual wages by 12.7 percent and hourly wages by 10.0 percent.

Female 2SLS coefficients are somewhat larger than OLS. The 2SLS coefficient for hours worked of 0.080 is more than twice the OLS magnitude but is imprecisely estimated and not significantly different from zero. Of greater interest, IV results indicate that an additional year of schooling increases female annual wages by 20.7 percent and hourly wages by 12.6 percent; both effects are significant at the one percent level. These may exceed corresponding OLS estimates because of measurement error in education attenuating OLS coefficients toward zero (Block et al. 2012). However, 2SLS produces larger standard errors than OLS because the instrumentinduced variation in schooling is much less than the total variation in schooling; e.g., first-stage $\mathrm{R}^{2}$ is less than 0.03 . Consequently, 2SLS and OLS coefficient estimates are not statistically significantly different.

\section{Conclusion}

This paper examines effects of schooling on worker wages. I instrument for schooling using cohort-level mean maternal schooling. 2SLS results suggest that an additional year of schooling causally increases hourly wages by 10.0 percent for men and 12.6 percent for women. 


\section{References}

Angrist, J.D., Pischke, J.S., 2009. Mostly Harmless Econometrics. Princeton: Princeton University Press.

Behrman, J.R., Rosenzweig, M.R., 2002. Does increasing women's schooling raise the schooling of the next generation? American Economic Review, 92(1), 323-334.

Björklund, A., Salvanes, K.G., 2011. Education and family background: Mechanisms and policies, in: Hanushek, E., Machin, S. Woessmann. L. (Eds.), Handbook of the Economics of Education, Vol. 3, Elsevier, 201-247.

Block, J.H., Hoogerheide, L., Thurik R. 2012. Are education and entrepreneurial income endogenous? A Bayesian analysis. Entrepreneurship Research Journal, 2(3): 1-27.

Card, D., 1999. The causal effect of education on earnings, in: Ashenfelter, O., Card, D. (Eds.), Handbook of Labor Economics, Vol. 3, Elsevier, 1801-1863.

Hoogerheide, L., Block, J.H., Thurik, R., 2012. Family background variables as instruments for education in income regressions: A Bayesian analysis. Economics of Education Review, 31(5): 515-523.

Psacharopoulos, G., Patrinos, H.A., 2004. Returns to investment in education: A further update. Education Economics, 12(2): 111-134.

Ruggles, S.J., Alexander,T., Genadek, K., Goeken, R., Schroeder, M.B., Sobek, M. 2010. Integrated Public Use Microdata Series: Version 5.0 [Machine-readable database]. Minneapolis: University of Minnesota.

Winters, J.V., 2014. The production and stock of college graduates for U.S. states. Working Paper. 
Table 1: Returns to Schooling for Native-Born Whites

\begin{tabular}{|c|c|c|c|c|c|c|}
\hline & $\begin{array}{c}(1) \\
\text { Male } \\
\text { Log } \\
\text { Annual } \\
\text { Wages }\end{array}$ & $\begin{array}{c}\text { (2) } \\
\text { Male } \\
\text { Log } \\
\text { Annual } \\
\text { Hours }\end{array}$ & $\begin{array}{c}\text { (3) } \\
\text { Male } \\
\text { Log } \\
\text { Hourly } \\
\text { Wages }\end{array}$ & $\begin{array}{c}(4) \\
\text { Female } \\
\text { Log } \\
\text { Annual } \\
\text { Wages }\end{array}$ & $\begin{array}{c}(5) \\
\text { Female } \\
\text { Log } \\
\text { Annual } \\
\text { Hours }\end{array}$ & $\begin{array}{c}(6) \\
\text { Female } \\
\text { Log } \\
\text { Hourly } \\
\text { Wages }\end{array}$ \\
\hline \multicolumn{7}{|l|}{ A. OLS Results } \\
\hline Years of Schooling & $\begin{array}{c}0.124 * * * \\
(0.002)\end{array}$ & $\begin{array}{c}0.028 * * * \\
(0.001)\end{array}$ & $\begin{array}{c}0.097 * * * \\
(0.001)\end{array}$ & $\begin{array}{c}0.134 * * * \\
(0.001)\end{array}$ & $\begin{array}{c}0.027 * * * \\
(0.001)\end{array}$ & $\begin{array}{c}0.107 * * * \\
(0.001)\end{array}$ \\
\hline \multicolumn{7}{|l|}{ B. 2SLS Results } \\
\hline Years of Schooling & $\begin{array}{c}0.127 * * \\
(0.063)\end{array}$ & $\begin{array}{c}0.027 \\
(0.034)\end{array}$ & $\begin{array}{c}0.100 * * \\
(0.049)\end{array}$ & $\begin{array}{c}0.207 * * * \\
(0.061)\end{array}$ & $\begin{array}{c}0.080 \\
(0.067)\end{array}$ & $\begin{array}{c}0.126 * * * \\
(0.047)\end{array}$ \\
\hline \multicolumn{7}{|l|}{ First-Stage } \\
\hline Mean Maternal Schooling & $\begin{array}{c}0.330 * * * \\
(0.040)\end{array}$ & $\begin{array}{c}0.330 * * * \\
(0.040)\end{array}$ & $\begin{array}{c}0.330 * * * \\
(0.040)\end{array}$ & $\begin{array}{c}0.260 * * * \\
(0.057)\end{array}$ & $\begin{array}{c}0.260 * * * \\
(0.057)\end{array}$ & $\begin{array}{c}0.260 * * * \\
(0.057)\end{array}$ \\
\hline Instrument F-Statistic & 66.85 & 66.85 & 66.85 & 20.91 & 20.91 & 20.91 \\
\hline
\end{tabular}

Note: Standard errors clustered by birth state.

**Significant at 5\% level; ***Significant at $1 \%$ level. 